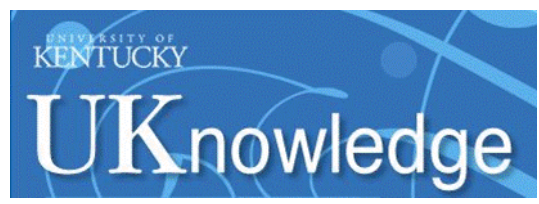

University of Kentucky

UKnowledge

\title{
Legume Cover Crops are More Beneficial than Natural Fallows in Minimally Tilled Ugandan Soils
}

Drake N. Mubiru

National Agricultural Research Organization, Kampala, Uganda

Mark S. Coyne

University of Kentucky, mark.coyne@uky.edu

Follow this and additional works at: https://uknowledge.uky.edu/pss_facpub

Part of the Plant Sciences Commons

Right click to open a feedback form in a new tab to let us know how this document benefits you.

\section{Repository Citation}

Mubiru, Drake N. and Coyne, Mark S., "Legume Cover Crops are More Beneficial than Natural Fallows in Minimally Tilled Ugandan Soils" (2009). Plant and Soil Sciences Faculty Publications. 3.

https://uknowledge.uky.edu/pss_facpub/3

This Article is brought to you for free and open access by the Plant and Soil Sciences at UKnowledge. It has been accepted for inclusion in Plant and Soil Sciences Faculty Publications by an authorized administrator of UKnowledge. For more information, please contact UKnowledge@lsv.uky.edu. 


\title{
Legume Cover Crops are More Beneficial than Natural Fallows in Minimally Tilled Ugandan Soils
}

\author{
Digital Object Identifier (DOI) \\ http://dx.doi.org/10.2134/agronj2007.0391 \\ Notes/Citation Information \\ Published in Agronomy Journal, v. 101, no. 3, p. 644-652.
}

The copyright holder has granted the permission for posting the article here. 


\title{
Legume Cover Crops are More Beneficial than Natural Fallows in Minimally Tilled Ugandan Soils
}

\author{
Drake N. Mubiru and Mark S. Coyne*
}

\begin{abstract}
It is important to establish the various effects of legume cover crops on soil physicochemical properties because they have been considered for use as improved fallows (with shorter rest periods) to enhance development and maintenance of soil productivity. Our objectives were to assess: (i) aboveground dry matter yields of legume cover crops; and (ii) cover crop effects on weed infestation and soil physicochemical properties in a minimum tillage management system. Trials were conducted for $2 \mathrm{yr}$ at Kawanda Agricultural Research Institute and on farmers' fields in Mbale and Pallisa districts, eastern Uganda. The experiment layout was a Randomized Complete Block Design (RCBD) in a split-plot arrangement with four replications. Natural and improved fallows were established in the second cropping season of 2004. Cover crops used in the improved fallows included mucuna [Mucuna pruriens (L.) DC.var. utiliz], Dolichos lablab (Lablab vulgaris Savi cv. Rongai), canavalia [Canavalia ensiformis (L.) DC.], and crotalaria (Crotalaria paulina Schrank). The fallows were reestablished in the same plots in the second cropping season of 2005 after maize (Zea mays L.). Canavalia yielded significantly more dry matter than the other fallows regardless of year or site. With an average yield of $169 \mathrm{~kg} \mathrm{~N} \mathrm{ha}^{-1}$ canavalia accumulated significantly more $\mathrm{N}$ than the other fallows; all improved fallows produced significantly more $\mathrm{N}$ than the natural fallow. Canavalia also accumulated significantly more $\mathrm{P}$ than the other fallows; all improved fallows, with the exception of crotalaria, accumulated more $P$ than the natural fallow. There was no significant change in soil physicochemical properties by the improved fallows. All effects considered, improved fallows were more beneficial than natural fallow. A significant improvement in soil physicochemical properties using legume cover crops might be possible, though it may require more than the two cropping cycles used in this study of degraded soils.
\end{abstract}

$\mathrm{O}$ NE OF THE MAIN BIOPHYSICAL CAUSES of declining per capita food production in much of sub-Saharan Africa is soil fertility decline on smallholder farms (Sanchez et al., 1997). Food production has not kept pace with the regional average 3\% population growth rate per year. The rapid population growth has led to intensive and extensive land cultivation to support daily food and fiber needs. Consequently, fragile and marginal lands have been progressively encroached upon (Bojo, 1996), even against technical advice. Furthermore, continuous land cultivation for crop production without external inputs, and removal of crop residues (Sanchez et al., 1997; Wortmann and Kaizzi, 1998), have replaced the traditional fallow systems that were previously used to rejuvenate soil fertility and maintain sustainable food production (Nandwa and Bekunda, 1998). As a result, large areas have undergone serious soil physical, biological, and chemical deterioration (FAO, 2000) leading to declining soil productivity.

D.N. Mubiru, National Agricultural Research Laboratories InstituteKawanda, National Agricultural Research Organization (NARO), Box 7065 Kampala, Uganda; M.S. Coyne, Dep. of Plant and Soil Sciences, Univ. of Kentucky, 1100 S. Limestone St., Lexington, KY 40546-0091. Received 10 Dec. 2007. *Corresponding author (mscoyn00@email.uky.edu).

Published in Agron. J. 101:644-652 (2009).

doi:10.2134/agronj2007.0391

Copyright (C) 2009 by the American Society of Agronomy, 677 South Segoe Road, Madison, WI 53711. All rights reserved. No part of this periodical may be reproduced or transmitted in any form or by any means, electronic or mechanical, including photocopying, recording, or any information storage and retrieval system, without permission in writing from the publisher.
For Uganda in particular, soil productivity decline is evident across the country and manifest in $\mathrm{N}$ and $\mathrm{P}$ deficiencies (Bekunda et al., 1997) and extremely low crop yields. Agriculture in Uganda, as is the case with the rest of sub-Saharan Africa, is characterized by continuous cultivation without external inputs, nutrient mining, poor soil and water conservation, and low inherent soil fertility (Ssali et al., 1986) among other factors. Nutrient loss through crop harvest (mining), leaching, and erosion far exceeds nutrient inputs from fertilizers, atmospheric deposition, and biological nitrogen fixation (Smaling and Braun, 1996). This imbalance has led to deficiencies in essential plant nutrients (Bekunda et al., 1997; Wortmann and Kaizzi, 1998).

Farmers are unable to compensate for the losses by using inorganic fertilizers due to high costs, which are attributed to high freight charges because Uganda is landlocked (Wejuli et al., 2001) and farmers' insufficient knowledge of fertilizer forms, methods of use, and the potential benefits accruing from their use (Bekunda et al., 1997). Relying on crop residues for agricultural production is not sustainable among smallholder farmers. Such farmers are unable to compensate for the nutrient losses due to the demand for manure and crop residues as fuel and fodder (Palm et al., 1997) and the sheer volumes required to meet the need of crops.

Conservation agriculture (CA) in the form of minimum tillage and maintenance of a soil cover has led to sustainable land productivity in the Americas (Bwalya and Friedrich, 2002) but has not been adequately exploited in Africa (Lal, 1986); yet it

Abbreviations: CA, conservation agriculture; masl, meters above sea level; RCBD, Randomized Complete Block Design; SOM, soil organic matter. 
can be a remedy for soil fertility problems on the continent. The major benefits associated with minimum tillage include, but are not limited to, minimal disruption of soil structure, hence, optimizing infiltration and maintenance of higher levels of organic matter, ensuring soil health, and promoting soil fauna biodiversity and microbial activities (Ferreira et al., 2000). Most soils in Uganda are highly weathered; therefore, inherent fertility is low and soil organic matter is important to maintain good soil physical properties and as the main source of crop nutrients (Ssali and Vlek, 2002).

Maintaining soil cover through the use of legume cover crops (improved fallows) and keeping plant residues on the soil surface preserves and fosters organic matter balances in the soil (Dick, 1982; Calegari, 1998). Improved fallow is a green-manure farming system that is used as a partial fallow replacement in a crop-fallow rotation, while natural fallows are overly grass-based. Because agriculture in Uganda is rain-fed, the cropping seasons coincide with the rainy seasons. The rest periods that automatically follow the cropping seasons are the natural fallows. Improved fallows are deliberately established either in pure stands at the beginning of the rainy season and left to grow through the dry season until the beginning of the following rainy season or are planted toward the end of the rainy season, in fields where food crops such as maize are about to be harvested, and left to grow through the dry season until the beginning of the following rainy season, a practice known as relay cropping.

In addition, as part of the production system, cover crops are economically feasible and ecologically sustainable, leading to greater crop productivity, soil and water conservation, and maintenance and recovery of soil fertility (Calegari, 2001). Furthermore, legume cover crops promote economy with nitrogenous fertilizers (Welty et al., 1988; Campbell et al., 1991, 1992), and greater biological balance in the soil (Calegari, 2001), thus decreasing the effects of pests and diseases.

These parameters are essential in maintaining soil productivity especially under resource poor and smallholder conditions. However, there is still need to evaluate the conservation agriculture system, especially the various effects of legume cover crops, and to ascertain their benefits to agricultural production systems in the local environment. The objectives of this study were to: (i) assess aboveground dry matter yields and nutrient accumulation of legume cover crops; and (ii) assess the effect of legume cover crops on weed infestation and soil physicochemical properties in a minimum tillage management system.

\section{MATERIALS AND METHODS}

\section{Location Characteristics}

Trials were conducted between 2004 and 2006 at Kawanda Agricultural Research Institute and in two rural parishes, Petete, Pallisa district and Busiu, Mbale district, in eastern Uganda. Kawanda, is located $0^{\circ} 25^{\prime} 05^{\prime \prime} \mathrm{N}$ and $32^{\circ} 31^{\prime} 54^{\prime \prime} \mathrm{E}$ at 1190 meters above sea level (masl), average rainfall is $1224 \mathrm{~mm}$ per annum. Petete is at 1071 masl with an average rainfall of $1000 \mathrm{~mm}$ per annum. Busiu is at $1215 \mathrm{masl}$ and average rainfall is $1191 \mathrm{~mm}$ per annum. Each site has two rainfall seasons: long rains last from March to June while short rains last from September to November. Dry seasons-December to February and July to August are characterized by none to few low intensity isolated showers (Fig. 1A) and higher maximum temperatures (Fig. 1B).

The soils from the research sites were sandy, with sand contents ranging from 560 to $830 \mathrm{~g} \mathrm{~kg}^{-1}$ (Table 1). Soil from the trial field at Kawanda Agricultural Research Institute was a sandy clay. Soil from Pallisa was a sandy loam. Soil from Mbale was a loamy sand. The soil textures are typical for these areas (Ssali, 2000).

\section{Farmer Selection and Experiment Design}

Lists of farmers were obtained from Local Council 1 chairpersons and, with assistance from field extension officers, farmers were stratified on the basis of landholding size, food and cash crops grown, and intensity of soil and water conservation. Four farmers with almost equal landholdings and similar management practices were selected from each parish. The experiment layout was a RCBD in a split-plot arrangement with four replications. Fallow management was the main plot and the fallows were the subplots. The fallows were managed in preparation of the following cropping season either by slashing or by herbicide application ( $50 \%$ glyphosate [ $N$-(phosphonomethyl) glycine]) at $3 \mathrm{~L} \mathrm{ha}^{-1}$. Slashing involved cutting the aboveground dry matter as close to the soil surface as possible and allowing the dry matter to settle on the soil surface.

Improved fallows in pure stands and a natural fallow were established in 4 by $4 \mathrm{~m}$ subplots during the short rains of 2004. Cover crops used in the improved fallows included mucuna, lablab, canavalia, and crotalaria. All improved fallows were seeded at a spacing of 75 by $60 \mathrm{~cm}$. The seeds were hand-planted using a sharp stick to pierce the soil surface, allowing for minimum soil disturbance. The fallows were reestablished in the same plots in the second cropping season of 2005 after a crop of maize.

\section{Data Collection and Analysis}

A baseline soil analysis was performed by taking soil samples from the 0 - to $20-\mathrm{cm}$ depth from each trial field. The samples were dried in open air, ground to pass a $2-\mathrm{mm}$ sieve, and analyzed according to Foster (1971) and Okalebo et al. (2002). Texture analysis was performed using the hydrometer method (Blake and Hartge, 1986b). Soil pH was measured using a soil/water ratio of 1:2.5. Extractable $\mathrm{P}, \mathrm{K}$, and $\mathrm{Ca}$ were measured in a single ammonium lactateacetic acid extract buffered at pH 3.8 (Okalebo et al., 2002). Total $\mathrm{N}$ was determined using a micro-Kjeldahl block digestion apparatus, and soil organic matter was determined by acid-dichromate digestion. Soil samples were also collected at the end of each fallow period and analyzed as above. After one season of fallow, soil samples were collected using a double-cylinder, hammer driven core sampler to determine bulk density (Blake and Hartge, 1986a).

At the fallow flowering stage, a $0.25-\mathrm{m}^{2}$ quadrant placed at four random positions within each plot was used to determine the accumulated aboveground dry matter. Plant samples were dried in an oven at $70^{\circ} \mathrm{C}$, ground to pass a 0.5-mm sieve, and analyzed for $\mathrm{Ca}, \mathrm{Mg}, \mathrm{K}, \mathrm{P}$, and total $\mathrm{N}$ by wet oxidation (Parkinson and Allen, 1975). Phosphorus was 

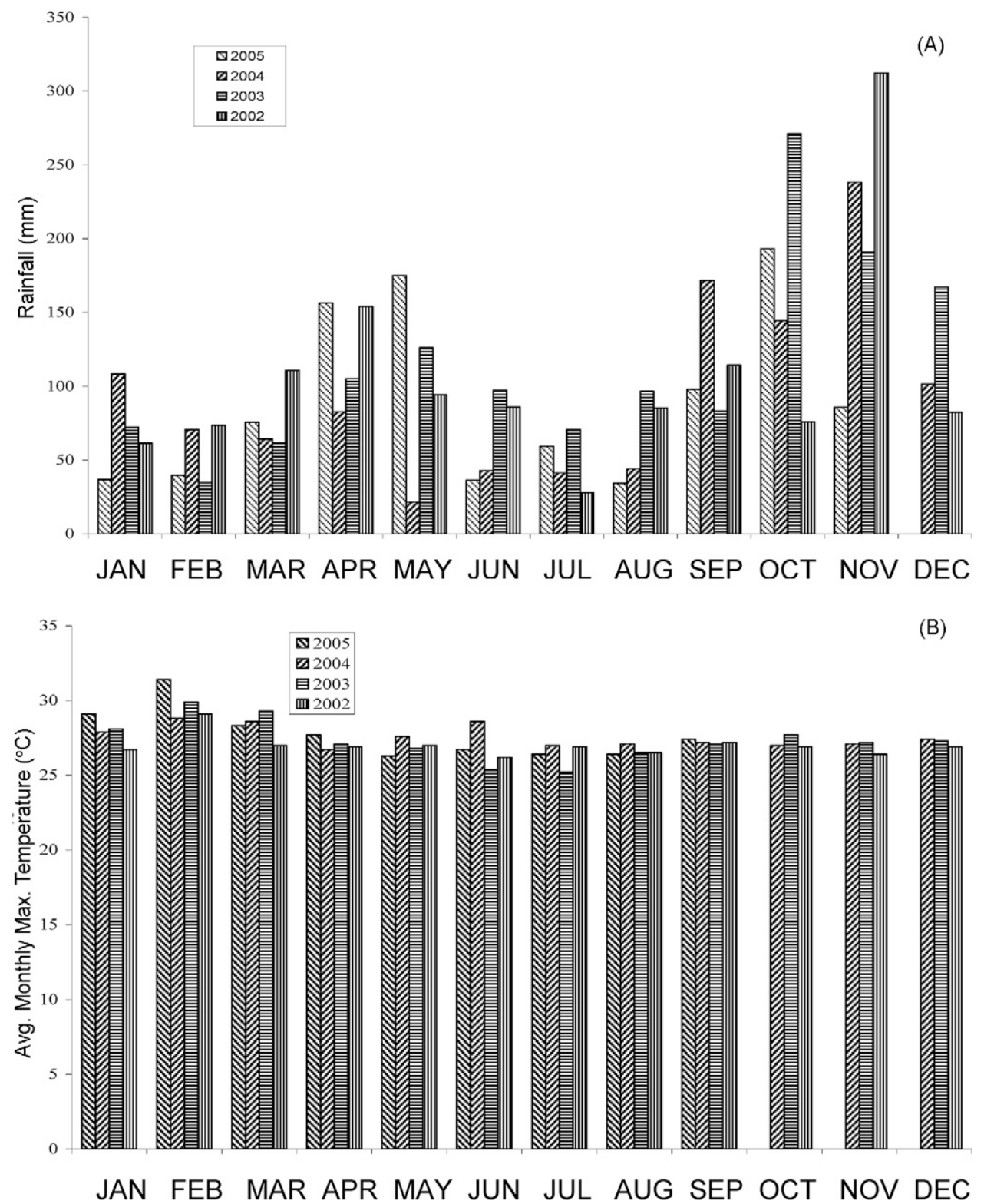

Fig. I. Mean monthly (a) rainfall and (b) maximum temperature at Kawanda from 2002 to 2005. determined colorimetrically, and $\mathrm{K}$ was determined by flame photometry (Okalebo et al., 2002).

\section{Weeds}

Weed densities were determined by counting all weed species enclosed in a $0.25-\mathrm{m}^{2}$ quadrant placed at three random positions within each subplot. Individual weed species were counted separately to establish the percentage of particular weed species per quadrant. The weeds were counted 3 wk after the fallows had either been slashed or sprayed with herbicide. Plant specimens were collected, labeled, pressed, and dried for identification at Makerere University herbarium.

\section{Statistical Analysis}

Data was examined by ANOVA to determine significant $(P<0.05)$ site, management, and fallow effects and treatment interactions. For variables in which significant treatment interactions were detected, ANOVA was performed on data within each site or management system. Comparison of means were made by LSD all-pair-wise comparisons. All analyses were done using Statistix V. 2.0 (Statistix for Windows, 1998).
Table I. Baseline average soil physicochemical properties at the three study sites.

\begin{tabular}{lcccc}
\hline & \multicolumn{4}{c}{ Site } \\
\cline { 2 - 5 } \multicolumn{1}{c}{ Property } & Kawanda & Pallisa & Mbale & $\begin{array}{c}\text { Critical } \\
\text { values† }\end{array}$ \\
\hline pH I:2.5 & 4.5 & 5.9 & 6.4 & 5.2 \\
SOM, \% & 2.7 & 1.6 & 1.3 & 3.0 \\
Total N, \% & 0.12 & 0.16 & 0.14 & 0.20 \\
Extractable P, mg kg-1 & 2.14 & 0.52 & 5.6 & 5.0 \\
Extractable K, mg kg-1 & 151 & 135 & 142 & 150 \\
Extractable Ca, mg kg-1 & 1078 & 612 & 652 & 350 \\
Extractable Mg, mg kg-1 & 198 & 228 & 171 & na \\
Sand, g kg-1 & 560 & 730 & 830 & na \\
Silt, g kg-1 & 70 & 80 & 75 & na \\
Clay, g kg & 370 & 190 & 95 & na \\
\hline
\end{tabular}

† Levels below the critical values are considered to be yield limiting (Foster, 197I); na = not applicable.

\section{RESULTS AND DISCUSSION}

\section{Baseline Soil Physicochemical Properties}

Soil organic matter (SOM) was below a critical value of 3.0\% at all three sites (Table 1). Soil organic matter levels between 3 and 6\% are considered adequate for surface soils in Uganda (Foster, 1971), although Foster (1981) demonstrated that a positive response to fertilizer in several crops could occur in soils when organic matter was less than $3.5 \%$. The soil particlesize analysis and SOM results (Table 1) show that Pallisa and Mbale are on lighter soils with less SOM; accordingly the cropping systems in these areas are predominantly annual. Kawanda, which had the highest clay and SOM content, is located in the medium altitude areas with largely perennial cropping systems.

Soil $\mathrm{pH}$ at Kawanda was below a critical value of 5.2, while at Pallisa and Mbale it was above the critical value (Table 1). Kawanda is situated in the intensive banana-coffee (Musa sapientum L.-Coffea arabica L.) lakeshore farming system and 


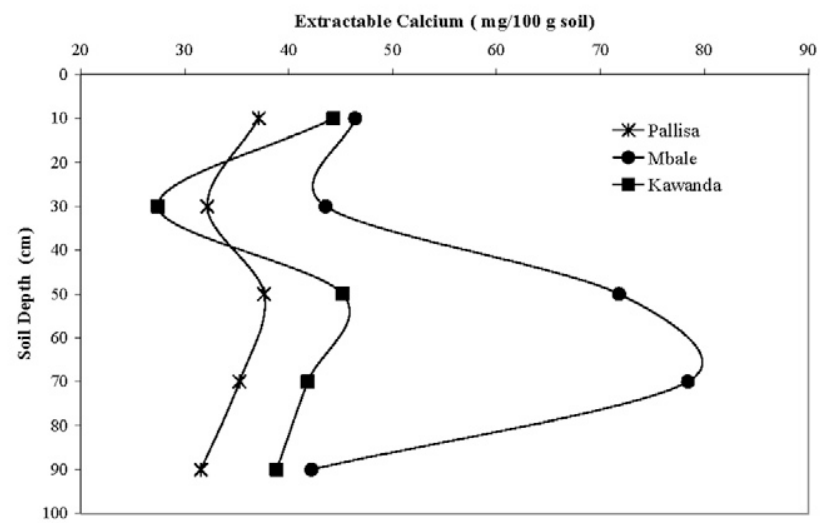

Fig. 2. Variation of extractable calcium with soil depth for soils from Kawanda, Pallisa, and Mbale.

many soils in this area have $\mathrm{pH}$ levels below the critical value (Ssali and Vlek, 2002; Foster, 1976). The $\mathrm{pH}$ trend across the sites observed in this study is attributable to the fact that lowrainfall areas experience little leaching of base-forming cations to lower soil horizons, which results in a relatively high degree of base saturation and $\mathrm{pH}$. However, in more humid areas, such as the medium altitude and along the shores of Lake Victoria, leaching depletes the upper horizon of calcium and other baseforming cations as exhibited in Fig. 2.

On average, all three sites had sufficient extractable Ca according to the critical level (Table 1). Sufficient extractable K was observed at Kawanda only. Sufficient extractable $P$ was observed only at Mbale. All sites had insufficient total N. Most soils in Uganda are characterized by low fertility, mainly $\mathrm{N}$ and P deficiencies (Bekunda et al., 1997). However, the soils in Mbale are derived from volcanic ash, and such soils are documented to have high levels of available P (Ssali, 2001). The low levels of $\mathrm{K}$ at Pallisa and Mbale are arguably a result of continuous cultivation and/or aboveground plant dry matter removal in harvests or livestock grazing. Plants take up about the same amount of $\mathrm{K}$ as $\mathrm{N}$ and five to 10 -fold as much $\mathrm{K}$ as $\mathrm{P}$ (Brady and Weil, 1996, p. 479); therefore, continuously cropped soils lose available $\mathrm{K}$ more rapidly than other nutrients, which is manifest in large responses to $\mathrm{K}$ fertilizers in continuously cropped trials (Ssali, 2001). In addition, the drain on the soil supply of $\mathrm{K}$ can be very large if most or all of the aboveground parts are removed in harvest (Brady and Weil, 1996, p. 479).

The insufficient levels of N, P, and K pose a major concern, signaling the urgent need for management attention if sustainable crop productivity is to be achieved.

\section{Fallow Aboveground Dry Matter Production}

In 2004, there were significant differences in fallow aboveground dry matter yield among sites (Table 2). The mean yield at Pallisa of $4.23 \mathrm{Mg} \mathrm{ha}^{-1}$ was significantly higher than that at Mbale (3.41 Mg ha ${ }^{-1}$ ) and Kawanda $\left(3.11 \mathrm{Mg} \mathrm{ha}^{-1}\right)$, but differences between Mbale and Kawanda were not significant. Dry matter yield was also significantly different among the fallows. However, there were significant site $\times$ fallow interactions; therefore, ANOVA was performed on data within each site (Table 2). At Kawanda and Pallisa, the cavanalia fallow yielded significantly more dry matter than the other fallows, but no

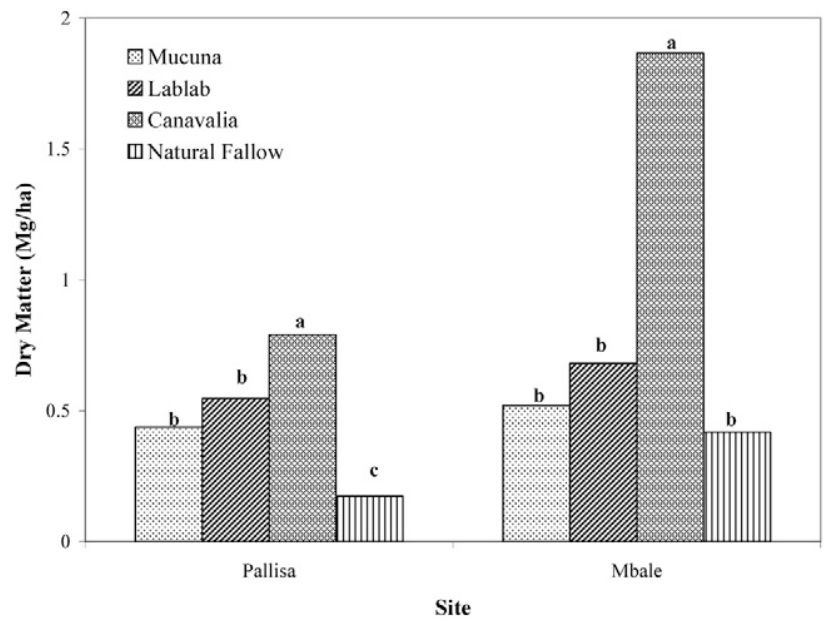

Fig. 3. Fallow aboveground dry matter yield at two of the study sites in 2005. Means are different according to the LSD method $(P<0.05)$ if different letters appear above bars within each site.

other differences were significant. The canavalia fallow also had the highest yield at Mbale, but differences were only significant between canavalia and the natural fallow or lablab. Elsewhere, Aleman and Flores (1993) also observed high aboveground dry matter yield by canavalia, which they attributed to its broad leaves and large sized seedpods.

In 2005, most areas across the country experienced below normal rainfall, and the performance of the fallows was very poor compared with the previous year. At Kawanda, for example, the cumulative rainfall was $991.1 \mathrm{~mm}$, which was $19 \%$ below the normal average $\left(1224 \mathrm{~mm} \mathrm{yr}^{-1}\right)$.

Consequently, all improved fallows failed at Kawanda, while at Pallisa and Mbale there was total failure of crotalaria. The mean fallow dry matter yield was significantly higher at Mbale than Pallisa (0.84 vs. $0.52 \mathrm{Mg} \mathrm{ha}^{-1}$ ) (Fig. 3). Dry matter yield was also significantly different among the fallows. Just as in 2004, there were significant site $\times$ fallow interactions; therefore, ANOVA was performed on data within each site (Fig. 3). It is worth noting that during the $2 \mathrm{yr}$ of the study (with normal and below normal rainfall) and at all study sites, canavalia yielded the highest dry matter relative to the other fallows. Apparently it was the cover crop most tolerant to drought. Other studies have also reported canavalia to be drought resistant (Bunch, 1993). Crotalaria totally failed across the sites in 2005. It can therefore be safely concluded that it was the least tolerant to drought. Crotalaria is small seeded, and according to Egli (1998) the initial growth rate of a seedling is

Table 2. Fallow aboveground dry matter yield in 2004. $\dagger$

\begin{tabular}{lccl}
\hline \multirow{2}{*}{ Fallow } & \multicolumn{3}{c}{ Dry matter yield } \\
\cline { 2 - 4 } Kawanda & Pallisa & Mbale \\
\cline { 2 - 4 } Crotalaria & $2.23 \mathrm{~b}$ & $3.64 \mathrm{~b} \mathrm{~b}^{-1}$ & $3.89 \mathrm{ab}$ \\
Mucuna & $2.80 \mathrm{~b}$ & $3.76 \mathrm{~b}$ & $3.60 \mathrm{ab}$ \\
Lablab & $2.85 \mathrm{~b}$ & $3.57 \mathrm{~b}$ & $2.12 \mathrm{~b}$ \\
Canavalia & $4.99 \mathrm{a}$ & $8.55 \mathrm{a}$ & $5.29 \mathrm{a}$ \\
Natural fallow & $2.67 \mathrm{~b}$ & $1.62 \mathrm{~b}$ & $2.13 \mathrm{~b}$ \\
Mean & $3.1 \mathrm{lb}$ & $4.23 \mathrm{a}$ & $3.4 \mathrm{lb}$ \\
\hline
\end{tabular}

† Different letters within each column or row (site means) indicate statistica difference between fallows and sites at $P=0.05$ level, using the LSD method. 


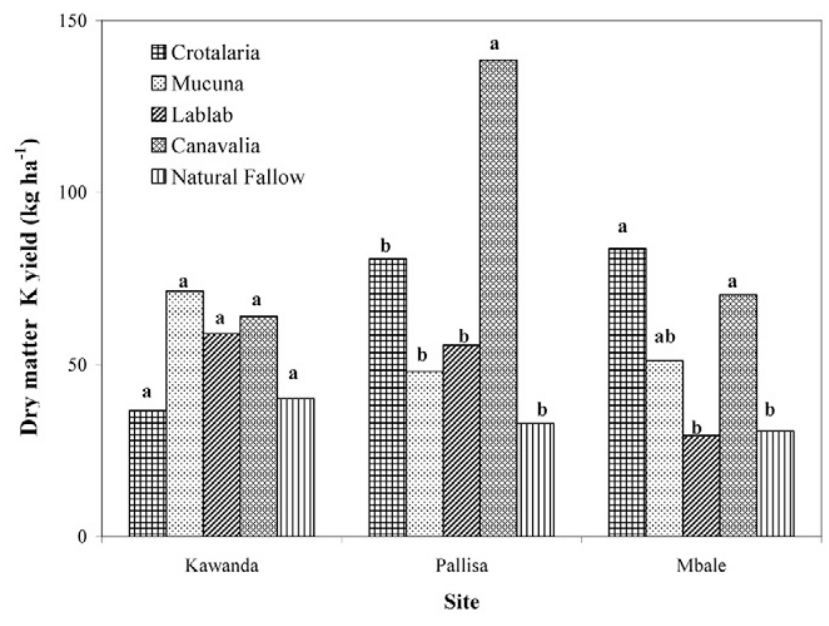

Fig. 4. Fallow aboveground dry matter $\mathrm{K}$ yield at the three study sites in 2004. Means are different according to the LSD method $(P<0.05)$ if different letters appear above bars within each site.

determined by its seed size. Therefore, under suboptimal conditions, as was the case in 2005, there might have been difficulty in crotalaria establishment. Fischler (1997) also reported difficulty in crotalaria establishment, which he attributed to its small seed size.

\section{Fallow Aboveground Dry Matter Nutrient Accumulation}

In 2004, there were no significant site differences in the fallow aboveground dry matter N, P, and K yields. However, significant site differences were observed for $\mathrm{Ca}$ and $\mathrm{Mg}$ yields. There were also significant site $\times$ fallow interactions for $\mathrm{K}, \mathrm{Ca}$, and $\mathrm{Mg}$, which indicated that for these nutrients fallow effects were not independent of site effects.

Because there were no significant site $\times$ fallow interactions for $\mathrm{N}$ and $\mathrm{P}$, fallow means for these nutrients were averaged across the sites (Table 3). Canavalia accumulated significantly more $\mathrm{N}$ than the other fallows, while all improved fallows accumulated significantly more $\mathrm{N}$ than the natural fallow. With $169 \mathrm{~N} \mathrm{~kg} \mathrm{ha}^{-1}$, canavalia was the most efficient cover crop at accumulating $\mathrm{N}$ among the improved fallows. Canavalia also accumulated significantly more $P$ than the other fallows, and all improved fallows, with the exception of crotalaria, accumulated more $\mathrm{P}$ than the natural fallow (Table 3). Phosphorus is a major limiting factor for crop production on many tropical and subtropical soils (Norman et al., 1995; Manske et al., 2001; van der Eijk et al., 2006) as a result of high P fixation (Mubiru and

Table 3. Fallow aboveground dry matter $\mathbf{N}$ and $\mathbf{P}$ yields across the study sites $\uparrow$ (2004).

\begin{tabular}{lcc}
\hline & \multicolumn{2}{c}{ Nutrient yield } \\
\cline { 2 - 3 } \multicolumn{1}{c}{ Fallow } & $\mathbf{N}$ & $\mathbf{P}$ \\
\cline { 2 - 3 } Crotalaria & $95 \mathrm{~b}$ & $\mathrm{~kg} \mathrm{ha}^{-1}$ \\
Mucuna & $93 \mathrm{~b}$ & $5.05 \mathrm{bc}$ \\
Lablab & $75 \mathrm{~b}$ & $6.47 \mathrm{~b}$ \\
Canavalia & $169 \mathrm{a}$ & $5.64 \mathrm{~b}$ \\
Natural fallow & $30 \mathrm{c}$ & $10.58 \mathrm{a}$ \\
\hline
\end{tabular}

$\dagger$ Different letters within each column indicate statistical difference between fallows at $P=0.05$ level, using the LSD method.

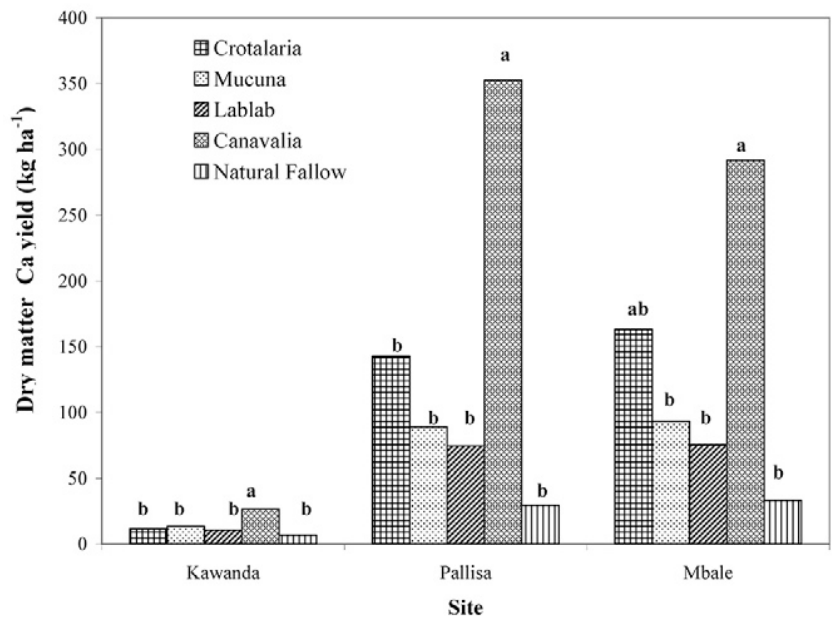

Fig. 5. Fallow aboveground dry matter $\mathrm{Ca}$ yield at the three study sites in 2004. Means are different according to the LSD method $(P<0.05)$ if different letters appear above bars within each site.

Karathanasis, 1994; Osiname et al., 2000) and nutrient mining in traditional land systems (Vlek, 1993; Sanchez et al., 1997). Given the limited access of most smallholder farmers to fertilizer $\mathrm{P}$, it is desirable to identify and incorporate into cropping systems plant species that can mobilize P from soil-P pools, which are unavailable to less P-efficient food crops (Kamh et al., 1999). It emerged from this study that canavalia is not only good at fixing $\mathrm{N}$, but also effective at accumulating $\mathrm{P}$.

Due to the significant site $\times$ fallow interactions for $\mathrm{K}, \mathrm{Ca}$, and $\mathrm{Mg}$, data for each site was considered separately. There were no significant fallow effects on dry matter $\mathrm{K}$ yield at Kawanda (Fig. 4). However, at Pallisa, canavalia accumulated significantly more $\mathrm{K}$ than all other fallows while at Mbale, crotalaria had the highest dry matter K yield, although not significantly greater than mucuna or canavalia (Fig. 4). Fallow yields of $\mathrm{Ca}$ and $\mathrm{Mg}$ at Kawanda were much lower than at Mbale and Pallisa (Fig. 5 and 6). This could have been due to the low inherent soil $\mathrm{Ca}$ and $\mathrm{Mg}$ at Kawanda manifest in the low $\mathrm{pH}$ at the beginning of the study (Table 1). At the three study sites

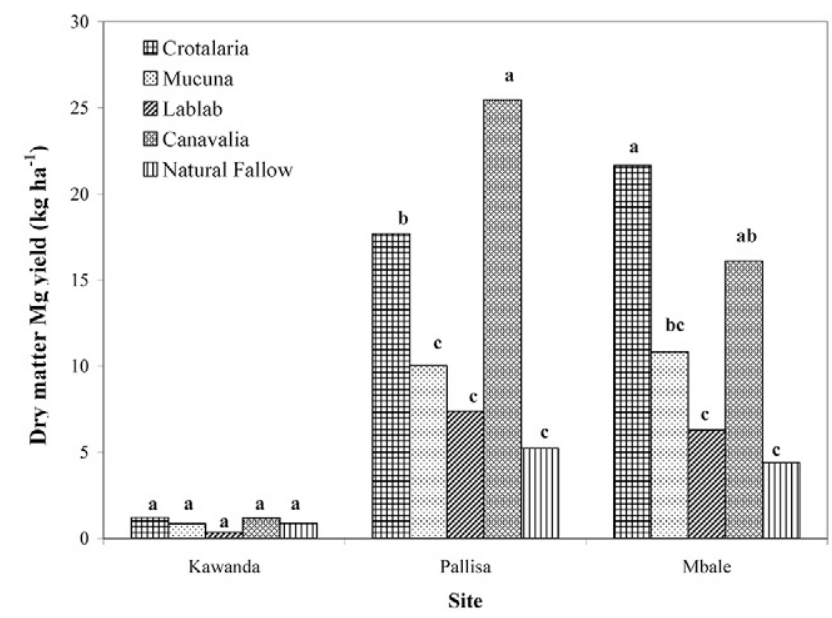

Fig. 6. Fallow aboveground dry matter $\mathrm{Mg}$ yield at the three study sites in 2004. Means are different according to the LSD method $(P<0.05)$ if different letters appear above bars within each site. 
Table 4. Fallow aboveground dry matter $\mathbf{N}$ and $\mathrm{Mg}$ yields across the study sites $†$ (2005). There was total failure of crotalaria at all sites.

\begin{tabular}{lcc}
\hline & \multicolumn{2}{c}{ Nutrient yield } \\
\cline { 2 - 3 } \multicolumn{1}{c}{ Fallow } & $\mathbf{N}$ & $\mathbf{M g}$ \\
\cline { 2 - 3 } Crotalaria & - & $\mathrm{kg} \mathrm{ha}^{-1}$ \\
Mucuna & $8.05 \mathrm{~b}$ & - \\
Lablab & $9.35 \mathrm{~b}$ & $2.14 \mathrm{~b}$ \\
Canavalia & $21.49 \mathrm{a}$ & $2.43 \mathrm{~b}$ \\
Natural fallow & $2.50 \mathrm{~b}$ & $4.33 \mathrm{a}$ \\
\hline
\end{tabular}

† Different letters within each column indicate statistical difference between fallows at $P=0.05$ level, using the LSD method.

Table 5. Fallow aboveground dry matter $P, K$, and $\mathrm{Ca}$ yields at two of the study sitest (2005).

\begin{tabular}{|c|c|c|c|c|c|c|}
\hline \multirow[b]{3}{*}{ Fallow } & \multicolumn{6}{|c|}{ Nutrient yield } \\
\hline & \multicolumn{3}{|c|}{ Pallisa } & \multicolumn{3}{|c|}{ Mbale } \\
\hline & $\mathbf{P}$ & $\mathbf{K}$ & $\mathrm{Ca}$ & $\mathbf{P}$ & $\mathbf{K}$ & $\mathrm{Ca}$ \\
\hline & \multicolumn{6}{|c|}{$-\mathrm{kg} \mathrm{ha}^{-1}$} \\
\hline Crotalaria & - & - & - & - & - & - \\
\hline Mucuna & $0.44 a$ & $5.82 \mathrm{a}$ & $5.56 \mathrm{bc}$ & $0.72 \mathrm{a}$ & $7.06 \mathrm{~b}$ & $3.15 b$ \\
\hline Lablab & $0.89 a$ & $12.66 \mathrm{a}$ & $8.35 b$ & $0.70 \mathrm{a}$ & II.56b & II.24b \\
\hline Canavalia & $0.99 a$ & $15.35 \mathrm{a}$ & $13.30 \mathrm{a}$ & $2.19 a$ & $31.19 a$ & $32.49 a$ \\
\hline Natural fallow & $0.14 a$ & $3.35 \mathrm{a}$ & $2.05 c$ & $0.6 \mathrm{Ia}$ & $10.59 \mathrm{~b}$ & $5.36 \mathrm{~b}$ \\
\hline
\end{tabular}

† Different letters within each column indicate statistical difference between fallows at $P=0.05$ level, using the LSD method.

canavalia also showed significantly higher Ca yield relative to the other fallows except, at Mbale, where the Ca yield of canavalia was significantly higher than all fallows except crotalaria (Fig. 5). There were no significant fallow effects on dry matter Mg yield at Kawanda (Fig. 6). At Pallisa, canavalia had the highest dry matter Mg yield; at Mbale, it was crotalaria, though the difference between crotalaria and canavalia was not significant (Fig. 6).

In 2005, there were no significant site differences in aboveground dry matter $\mathrm{N}$ and $\mathrm{Mg}$ yields. However, significant site differences were observed for $\mathrm{P}, \mathrm{K}$, and Ca yields. There were also significant site $\times$ fallow interactions for $\mathrm{P}, \mathrm{K}$, and $\mathrm{Ca}$, which indicated that for these nutrients fallow effects were not independent of site effects.

Because there were no significant site $\times$ fallow interactions for $\mathrm{N}$ and $\mathrm{Mg}$, fallow means for these nutrients were averaged across the sites (Table 4). The canavalia fallow accumulated significantly more $\mathrm{N}$ and $\mathrm{Mg}$ than the other fallows. Due to the significant site $\times$ fallow interactions for $\mathrm{P}, \mathrm{K}$, and $\mathrm{Ca}$, data for each site was considered separately (Table 5). At Pallisa, there were no significant differences in fallow aboveground dry matter P and K yields. However, canavalia had the highest dry matter Ca yield relative to the other fallows and differences were significant. At Mbale, there were no significant differences in fallow aboveground dry matter P yields. However, canavalia accumulated significantly more $\mathrm{K}$ and $\mathrm{Ca}$ than the other fallows.

\section{Fallow Effects on Weeds}

The magnitude of weed infestation at the three study sites was variable (Table 6). The most important weeds in terms of weed density at Kawanda were, in order of decreasing infestation, nutgrass (Cyperus rotundus $\mathrm{L}$.) $>$ broadleaf woodsorrel (Oxalis latifolia Kunth) > benghal dayflower (Commelina
Table 6. Percent weed infestation at the three study sites and two management options. $\dagger$

\begin{tabular}{|c|c|c|c|c|}
\hline & \multicolumn{4}{|c|}{ Weed infestation } \\
\hline & Nutgrass & $\begin{array}{c}\text { Hairy } \\
\text { beggarticks }\end{array}$ & $\begin{array}{l}\text { Benghal } \\
\text { dayflower }\end{array}$ & $\begin{array}{c}\text { Broadleaf } \\
\text { woodsorrel }\end{array}$ \\
\hline \multicolumn{5}{|l|}{ Site } \\
\hline Kawanda & $39 a$ & $6 a$ & $12 a b$ & $13 a$ \\
\hline Pallisa & $12 b$ & Ila & $15 \mathrm{a}$ & - \\
\hline Mbale & $20 \mathrm{~b}$ & $6 a$ & $4 b$ & $\mathrm{Ila}$ \\
\hline \multicolumn{5}{|l|}{ Management } \\
\hline Slash & $35 a$ & $15 a$ & $18 a$ & $13 a$ \\
\hline Herbicide & $\mathrm{IIb}$ & $\mathrm{Ib}$ & $3 b$ & $3 a$ \\
\hline
\end{tabular}

benghalensis L.) > hairy beggarticks (Bidens pilosa L.). At Pallisa the order was benghal dayflower $>$ nutgrass $>$ hairy beggarticks while at Mbale it was nutgrass $>$ broadleaf woodsorrel $>$ hairy beggarticks $>$ benghal dayflower. Broadleaf woodsorrel was only common at Kawanda and Mbale.

There were significant site, management, and fallow effects on weed density. However, the site $\times$ management and management $\times$ fallow interactions were not significant. There was significantly more nutgrass at Kawanda than Pallisa and Mbale (Table 6). There was also significantly more benghal dayflower at Pallisa than Mbale but differences between Kawanda and Pallisa or Mbale were not significant. Densities of hairy beggarticks were not significantly different at the three study sites. At the management level, weed densities were significantly greater in the plots managed by slash relative to those managed by herbicides (Table 6). At the fallow level, significant fallow effects were only observed on nutgrass. The natural fallow had significantly more nutgrass infestation than lablab, but differences among the other fallows were not significant (Fig. 7).

It is plausible that the low levels of weed infestation at Pallisa and Mbale relative to Kawanda could have been as a result of continuous cultivation in the farmers' fields. The per-capita land holdings in Uganda have reduced by $90 \%$ (from approximately 8 to 1 ha per person) in a period spanning about nine decades. The small land holdings have precipitated the current scenario of continuous cultivation. Through continuous cultivation the reproductive cycles of the weeds may have been

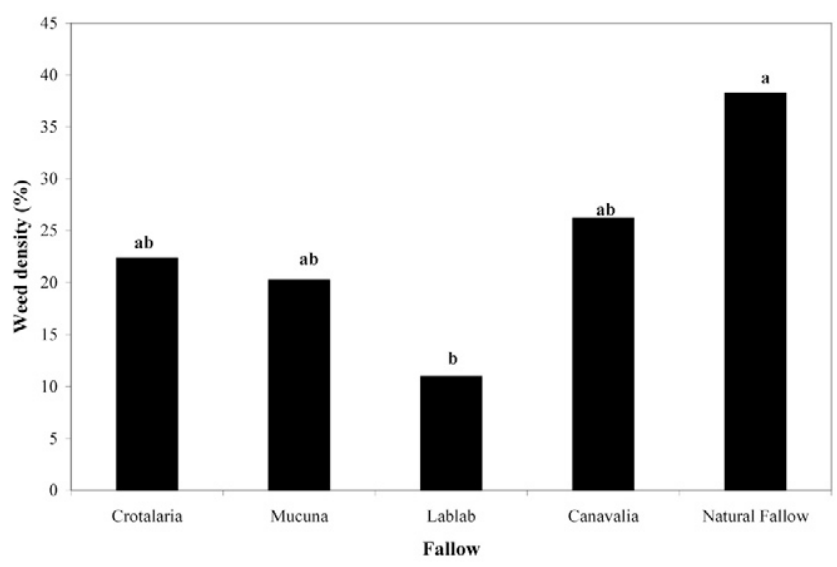

Fig. 7. Nutgrass (Cyperus rotundus L.) weed densities among the different fallows. Means are different according to Tukey's HSD $(P<0.05)$ if different letters appear above bars within each site. 
Table 7. Soil bulk density as affected by year, site, management, and fallow.

\begin{tabular}{lccc}
\hline & \multicolumn{3}{c}{ Bulk density } \\
\cline { 2 - 4 } Variable & Mean & CV & No. of samples \\
\hline Year & Mg m ${ }^{-3}$ & $\%$ & \\
2004 & & & 110 \\
2005 & $1.21 \mathrm{a}$ & 14.1 & 110 \\
Site & $1.19 \mathrm{a}$ & 13.4 & \\
$\quad$ Kawanda & & & 80 \\
Pallisa & $1.18 \mathrm{~b}$ & 10.8 & 80 \\
Mbale & $1.27 \mathrm{a}$ & 11.8 & 60 \\
Management & $1.15 \mathrm{~b}$ & 17.6 & 110 \\
$\quad$ Slash & & & 110 \\
$\quad$ Herbicide & $1.20 \mathrm{a}$ & 12.3 & \\
Treatment & $1.20 \mathrm{a}$ & 15.2 & 44 \\
$\quad$ Crotalaria & & & 44 \\
$\quad$ Mucuna & $1.19 \mathrm{a}$ & 12.9 & 44 \\
$\quad$ Lablab & $1.20 \mathrm{a}$ & 17.3 & 44 \\
$\quad$ Canavalia & $1.19 \mathrm{a}$ & 11.4 & 44 \\
$\quad$ Natural fallow & $1.19 \mathrm{a}$ & 11.1 & \\
\hline
\end{tabular}

disrupted. They are not allowed to flower and set seed; thus in the process subsequent levels of infestation are lowered. The higher infestation observed in the plots managed by slash relative to those managed by herbicide could be attributed to the higher rate of residue decomposition under slash management; this left scanty soil cover that did not effectively inhibit weed seeds from germinating.

The low infestation by nutgrass observed in the lablab fallow could have been a result of allelopathic suppression, seed germination inhibition due to the high cover crop residues, or both. According to Barreto (1994) and Parr et al. (1990), creeping and faster growing cover crops suppress weed growth by out-competing them for nutrients, moisture, space, and light. Schenk and Werner (1991) reported that various legumes in the tribe Vicieae (peas, lentils, and vetches) contain beta-(3-isoxazolinonyl) alanine, which is released into soil as a root exudate. This chemical can cause reduced growth in seedlings of various plants, and apparently is an allelopathic compound (Bugg, 1996). However, Frick and Johnson (2002) noted that it is a challenge to separate the effects of resource competition and allelopathy. Nonetheless, in this study it can be safely concluded that lablab, in rotation, may suppress nutgrass in subsequent crops.

\section{Fallow Effects on Soil Physicochemical Properties}

\section{Soil Bulk Density}

Bulk density did not significantly change at any site during the study (Table 7). However, the bulk densities at the three sites were significantly different. The mean bulk density at Mbale $\left(1.15 \mathrm{Mg} \mathrm{m}^{-3}\right)$ and Kawanda $\left(1.18 \mathrm{Mg} \mathrm{m}^{-3}\right)$ was significantly lower than that at Pallisa $\left(1.27 \mathrm{Mg} \mathrm{m}^{-3}\right)$. Fallow management and the fallows themselves had no significant effect on the soil bulk density, which was attributed to the short period during which the fallows were established. As observed by other workers (Voorhees and Lindstrom, 1984; Karunatilake et al., 2000; McGarry et al., 2000) benefits of improved fallows to soil in terms of bulk density and soil structure improvement typically require continuity and much longer periods to become manifest.

\begin{tabular}{|c|c|c|c|c|c|c|}
\hline Variable & pH & SOM & $\mathbf{N}$ & $\mathbf{P}$ & K & $\mathrm{Ca}$ \\
\hline \multicolumn{7}{|l|}{$\overline{\mathrm{pH}}$} \\
\hline OM & $-0.54 * *$ & & & & & \\
\hline $\mathrm{N}$ & $-0.52 * *$ & $0.86 * *$ & & & & \\
\hline$P$ & $0.31 * *$ & -0.11 & $-0.17 \ddagger$ & & & \\
\hline K & $0.74 * *$ & $-0.53 * *$ & $-0.40^{* * *}$ & 0.06 & & \\
\hline $\mathrm{Ca}$ & $0.72 * *$ & -0.14 & -0.05 & $0.27^{* *}$ & $0.75 * *$ & \\
\hline $\mathrm{Mg}$ & $0.66 * *$ & $-0.42^{* *}$ & $-0.25 * *$ & -0.01 & $0.85 * *$ & $0.84 * *$ \\
\hline
\end{tabular}

\section{Soil Chemical Properties}

In 2005, one season after establishing the fallows, there were no significant management or fallow effects in soil for OM, $\mathrm{pH}, \mathrm{N}, \mathrm{P}, \mathrm{K}, \mathrm{Ca}$, and $\mathrm{Mg}$. Kawanda had significantly more soil $\mathrm{OM}$ and $\mathrm{N}$ than Pallisa and Mbale; however, differences between Mbale and Pallisa were not significant. The trend Kawanda > Mbale > Pallisa was the same for SOM and N, indicating their interrelationship. Overall, there was a significant linear correlation between SOM and soil $\mathrm{N}(r=0.86$, $P<0.01)$ (Table 8). On the other hand, the trend Mbale > Pallisa > Kawanda was the same for $\mathrm{pH}, \mathrm{K}, \mathrm{Ca}$, and $\mathrm{Mg}$, apparently indicating an interrelationship between $\mathrm{pH}$ and the extractable bases depicted by the significant linear correlation coefficients ranging from $r=0.66$ to $0.74, P<0.01$ (Table 8). Other investigators (Foster, 1971, 1976) in Uganda found SOM to be significantly correlated with total $\mathrm{N}(r=0.92, P<0.01)$.

From Year 1 to Year 2, after one season of maize between the two fallow periods, there was a decrease in SOM, N, P, and $\mathrm{Ca}$. However, the decrease observed for $\mathrm{P}$ was not significant. On the other hand, there were significant increases in $\mathrm{pH}, \mathrm{K}$, and $\mathrm{Mg}$. The fact that the cover crops performed poorly in the second year could have contributed to the decrease in SOM due to poor dry matter production, whereas the decrease in $\mathrm{N}$ and Ca concentrations could have come as a result of leaching and poor recycling of nutrients. At the site level, there were highly significant differences in $\mathrm{SOM}, \mathrm{pH}, \mathrm{N}, \mathrm{P}, \mathrm{K}$, and $\mathrm{Ca}$, but differences in soil Mg were not significant. The trend Kawanda $>$ Mbale $>$ Pallisa was the same for SOM and N, whereas the trend Mbale $>$ Pallisa $>$ Kawanda was the same for $\mathrm{pH}, \mathrm{P}, \mathrm{K}$, and $\mathrm{Ca}$, as was the case in Year 1 . The natural fallow had relatively higher aboveground $\mathrm{K}$ and $\mathrm{Mg}$ concentrations (data not presented). Because the improved fallows did not establish well, there were more grasses, which probably led to the accumulation of soil $\mathrm{K}$ and $\mathrm{Mg}$.

Generally there was no significant improvement in the soil physicochemical properties by the improved fallows. Pikul et al. (1997) observed that an improvement in soil fertility using legume cover crops might be possible, though it might require many additional cropping cycles.

\section{CONCLUSIONS}

The nutrient status of the soils at the three study sites was attributed to the soil parent materials, climatic factors, and cultural practices. Differences in fallow aboveground dry matter production between the years and among the sites were partly a function of the differences in the weather conditions and the soil physicochemical properties. In turn, aboveground 
dry matter production was a major determinant of the aboveground dry matter nutrient accumulations. Cover crops that produced higher aboveground dry matter accumulated more nutrients. Continuous cultivation, resulting from socioeconomic problems such as population pressure, has led to a situation of low levels of weed infestation on farmers' fields at Pallisa and Mbale relative to the researcher-managed fields at Kawanda.

The relatively higher rate of residue decomposition under slash management left scanty soil cover, which did not effectively inhibit weeds seeds from germinating and was responsible for the higher levels of weed infestation observed in plots managed by slash compared with those managed by herbicide.

Plots with lablab fallow had the lowest nutgrass infestation, which was due to either allelopathic suppression, seed germination inhibition due to high cover crop residues, or both. Therefore, lablab may suppress nutgrass in a fallow-crop rotation cropping system. Canavalia yielded significantly more dry matter than the other fallows regardless of year or site. It also emerged to be the cover crop most tolerant to drought, whereas crotalaria was least tolerant. Generally, the canavalia fallow also had the highest aboveground dry matter nutrient yield. A combination of high dry matter and nutrient yield plus tolerance to drought made canavalia the best cover crop among those evaluated in this study.

Generally there was no significant improvement in the soil physicochemical properties by the improved fallows. In that regard, in addition to improved fallows, supplemental nutrients are required to improve the nutrient status of the soil. That notwithstanding, with all things considered, the improved fallows were more beneficial than the natural fallow because in most cases the natural fallow had the lowest aboveground nutrient concentrations and dry matter accumulation compared with the improved fallows. As has been observed by other investigators, a significant improvement on soil physicochemical properties using legume cover crops might be possible, though it might require many additional cropping cycles, especially on severely degraded soils.

\section{ACKNOWLEDGMENTS}

The authors are grateful to the participating farmers and the International Foundation for Science for the grant that enabled them to conduct the study. Additional support was provided the USDAARS Forage Animal Production Unit (FAPRU) under Agreement no. 3049022644. The investigation reported in this paper (07-06-133) is in connection with a project of the Kentucky Agricultural Experiment Station and is published with the approval of the Director. Mention of trade names is for information purposes only and does not imply endorsement by the Kentucky Agricultural Experiment Station or the USDA.

\section{REFERENCES}

Aleman, R., and M. Flores. 1993. Some data about canavalia (Canavalia ensiformis). Tech. No. 10. Centro Int. de Informacion Sobre Cultivos de Cobertura (CIDCCO), Honduras.

Barreto, H.J. 1994. Evaluation and utilization of different mulches and cover crops for maize production in Central America. p. 157-167. In H.D. Thurston et al. (ed.) Slash/mulch: How farmers use it and what researchers know about it. Cornell Int. Inst. for Food, Agric. and Development (CIFAD), Cornell Univ., Ithaca, NY.
Bekunda, M.A., A. Bationo, and H. Ssali. 1997. Soil fertility management in Africa: A review of selected research trials. p. 63-79. In R.J. Buresh et al. (ed.) Replenishing soil fertility in Africa. SSSA. Spec. Publ. 51. ASA and SSSA, Madison, WI.

Blake, G.R., and K.H. Hartge. 1986a. Bulk density. p. 363-375. In A. Klute et al. (ed.) Methods of soil analysis. Part 1. SSSA Book Ser. 5. SSSA, Madison, WI.

Blake, G.R., and K.H. Hartge. 1986b. Particle-size analysis. p. 383-411. In A. Klute et al. (ed.) Methods of soil analysis. Part 1. SSSA Book Ser. 5. SSSA, Madison, WI.

Bojo, J. 1996. The cost of land degradation in sub Saharan Africa. Ecol. Econ. 16:161-173.

Brady, N.C., and R.R. Weil. 1996. The nature and properties of soils. 11th ed. Prentice Hall, Upper Saddle River, NJ.

Bugg, R.L. 1996. Cover crop biology: A mini-review. Part 2. Sustainable Agric. Tech. Rev., Univ. of California.

Bunch, R. 1993. The use of green manures by village farmers: What we have learned to date. Tech. Rep. No. 3.Centro Int. de Informacion Sobre Cultivos de Corbertura (CIDICCO), Honduras.

Bwalya, M., and T. Friedrich. 2002. Conservation agriculture in development: The case of Africa. Proc. Int. Conf. on Animal Traction and Conservation Agric. 19-25 May 2002. Jinja, Uganda.

Calegari, A. 1998. Towards sustainable agriculture with a no-tillage system in South Brazil. p. 324. In Proc. Conservation Tillage for Sustainable Agric. 22-27 June 1998. Harare, Zimbabwe.

Calegari, A. 2001. Cover crop management. Proc. 1st World Congress on Conservation Agric. 1-5 Oct. 2001. Madrid, Spain.

Campbell, C.A., M. Schnitzer, G.P. Lafond, R.P. Zentner, and J.E. Knipfel. 1991. Thirty-year crop rotations and management practices effects on soil and amino nitrogen. Soil Sci. Soc. Am. J. 55:739-745.

Campbell, C.A., R.P. Zentner, F. Selles, V.O. Biederbeck, and A.J. Leyshon. 1992. Comparative effects of grain lentil-wheat and monoculture wheat on crop production, $\mathrm{N}$ economy, and $\mathrm{N}$ fertility in a Brown Chernozem. Can. J. Plant Sci. 72:1091-1107.

Dick, W.A. 1982. Organic carbon, nitrogen, and phosphorus concentrations and $\mathrm{pH}$ in soil profiles as affected by tillage intensity. Soil Sci. Soc. Am. J. 47:102-107.

Egli, D. 1998. Seed biology and the yield of grain crops. CAB Int., Wallingford, UK.

Ferreira, M.C., D.S. Andrade, L.M.O. Chueire, M. Tekemura, and M. Hungria. 2000. Tillage method and crop rotation effects on the population sizes and diversity of bradyrhizobia nodulating soybean. Soil Biol. Biochem. 32:627-637.

Fischler, M. 1997. Legume green manures in the management of maize-bean cropping systems in eastern Africa with special reference to crotalaria (C. ochroleuca G. Don.). Ph.D. diss. 12099. ETH Zurich.

Food and Agriculture Organization. 2000. Global assessment of soil degradation (GLASOD). FAO, Rome, Italy.

Foster, H.L. 1971. Rapid routine soil and plant analysis without automatic equipment: I. Routine soil analysis. E. Afric. Agric. For. J. 37:160-170.

Foster, H.L. 1976. Soil fertiltiy in Uganda. Ph.D. diss. Univ. of Newcastle Upon Tyne, UK.

Foster, H.L. 1981. The basic factors which determine inherent soil fertility in Uganda. J. Soil Sci. 32:149-160.

Frick, B., and E. Johnson. 2002. Using allelopathic cover crops to suppress weeds. Res. Rep. 2002. Scott Res. Farm Agri-food Innovation Fund, Saskatchewan, Canada.

Kamh, M., W.J. Horst, F. Amer, H. Mostafa, and P. Maier. 1999. Mobilization of soil and fertilizer phosphate by cover crops. Plant Soil 211:19-27.

Karunatilake, U., H.M. van Es, and R.R. Schindelbeck. 2000. Soil and maize response to plough and no-tillage after alfalfa-to-maize conversion on a clay loam soil in New York. Soil Tillage Res. 55:31-42.

Lal, R. 1986. No till farming, soil and water conservation and management in the humid and sub humid tropics. Monogr. no. 2. IITA, Ibadan, Nigeria.

Manske, G.G.B., J.I. Ortiz-Monasterio, M. van Ginkel, R.M. Gonzalez, R.A. Fischer, S. Rajaram, and P.L.G. Vlek. 2001. Importance of P uptake efficiency versus $\mathrm{P}$ utilization for wheat yield in acid and calcareous soils in Mexico. Eur. J. Agron. 14:261-274.

McGarry, D., U.P. Pillai, and M.V. Braunack. 2000. Optimizing soil structure condition for cropping without tillage. In J.E. Morrison, Jr. (ed.) ISTRO2000 [CD]. Proc. Int. Conf. of the Int. Soil Tillage Res. Org., 15th, Fort Worth, TX. 2-7 July 2000. Texas Agric. Exp. Stn., Fort Worth. 
Mubiru, D.N., and A.D. Karathanasis. 1994. Phosphorus-sorption characteristics of intensely weathered soils in south-central Kentucky. Commun. Soil Sci. Plant Anal. 25:2745-2759.

Nandwa, S.M., and M.A. Bekunda. 1998. Research on nutrient flows and balances in East and southern Africa: State-of-the-art. Agric. Ecosyst. Environ. 71:5-18.

Norman, M., C. Rearsonand, and P. Searle. 1995. The ecology of tropical food crops. Cambridge Univ. Press, Cambridge, UK.

Okalebo, J.R., K.W. Gathau, and P.L. Woomer. 2002. Laboratory methods of soil and plant analysis: A working manual. TSBF-CIAT and SACRED Africa, Nairobi, Kenya.

Osiname, O.A., F. Meppe, and L. Everett. 2000. Response of maize (Zea mays) to phosphorus application on basaltic soils in northwestern Cameroon. Nutr. Cycling Agroecosyst. 56:209-217.

Palm, C.A., R.J.K. Myers, and S.M. Nandwa. 1997. Combined use of organic and inorganic nutrient resources for soil fertility maintenance and replenishment. p. 193-217. In R.J. Buresh et al. (ed.) Replenishing soil fertility in Africa. SSSA Spec. Publ. 51. SSSA, Madison, WI.

Parkinson, J.A., and S.E. Allen. 1975. A wet oxidation procedure suitable for the determination of nitrogen and mineral nutrients in biological material. Commun. Soil Sci. Plant Anal. 6:1-11.

Parr, J.F., R.I. Papendick, S.B. Hornick, and R.E. Meyer. 1990. The use of cover crops, mulches and tillage for soil conservation and weed control. p. 246-261. In E. Pushparajah et al. (ed.) Organic-matter management and tillage in humid and sub-humid Africa. IBSRAM Proc. no. 10. Bangkok, Thailand.

Pikul, J.L., J.K. Aase, and V.L. Cochran. 1997. Lentil green manures as fallow replacement in the semiarid northern great plains. Agron. J. 89:867-874.

Sanchez, P.A., K.D. Shepherd, M.J. Soule, F.M. Place, R.J. Buresh, A.M.N. Izac, A.V. Mukwunye, F.R. Kwesiga, C.G. Ndirutu, and P.L. Woomer. 1997. Soil fertility replenishment in Africa: An investiment in natural resource capital. p. 1-46. In R.J. Buresh et al. (ed.). Replenishing soil fertility in Africa. SSSA Spec. Publ. 51. SSSA, Madison, WI.

Schenk, S.U., and D. Werner. 1991. Beta-(3-isoxazolin-5-on-2yl)-alanine from Pisum: Allelopathic properties and antimycotic bioassay. Phytochemistry 30:467-470.
Smaling, E.M.A., and A.R. Braun. 1996. Soil fertility research in Sub-Saharan Africa: New dimensions, new challenges. Commun. Soil Sci. Plant Anal. 27:365-386.

Ssali, H. 2000. Soil resources of Uganda and their relationships to major farming systems. Resource paper. Soils and Soil Fertility Management Program, Kawanda, NARO, Uganda.

Ssali, H. 2001. Soil fertility. p. 104-135. In J.K. Mukiibi. Agriculture in Uganda. Vol. 1. Fountain Publishers, Uganda.

Ssali, H., P. Ahn, and A.U. Mokwunye. 1986. Fertility of soils in tropical Africa: A historical perspective. p. 59-82. In A.V. Mokwunye and P.L.G. Vlek (ed.) Management of nitrogen and phosphorus fertilizers in sub-Saharan Africa. Martinus Nijhoff. Dordrecht, the Netherlands.

Ssali, H., and P.L.G. Vlek. 2002. Soil organic matter and its relationship to soil fertility changes in Uganda. Resource paper. Soils and Soil Fertility Management Program Annual Report, Kawanda, NARO, Uganda.

Statistix for Windows. 1998. Analytical Software, Tallahassee, FL.

van der Eijk, D., B.H. Janssen, and O. Oenema. 2006. Initial and residual effects of fertilizer phosphorus on soil phosphorus and maize yields on phosphorus fixing soils. A case study in south-west Kenya. Agric. Ecosyst. Environ. 116:104-120.

Vlek, P.G.L. 1993. Strategies for sustaining agriculture in sub-Saharan Africa. p. 265-277. In J. Rogland and R. Lal (ed.) Technologies for sustaining agriculture in the tropics. ASA Spec. Publ. 56. ASA, CSSA, and SSSA, Madison, WI.

Voorhees, W.B., and M.J. Lindstrom. 1984. Long-term effects of tillage method on soil tilth independent of wheel traffic compaction. Soil Sci. Soc. Am. J. 48:152-156.

Wejuli, M.S., H. Ssali, and C.K. Kaizzi. 2001. Livestock manures and compost production and use in Uganda. Uganda J. Agric. Sci. 7:37-41.

Welty, L.E., L.S. Prestbye, R.E. Engel, R.A. Larson, R.H. Lockerman, and R.S. Speilman. 1988. Nitrogen contribution of annual legumes to subsequent barley production. Appl. Agric. Res. 3:98-104.

Wortmann, C., and C.K. Kaizzi. 1998. Nutrient balances and expected effects of alternative practices in farming systems of Uganda. Agric. Ecosyst. Environ. 71:115-129. 